\title{
RECONSTRUCTION OF THE GLACIAL ICE COVERS OF GREENLAND AND THE CANADIAN ARCTIC ISLANDS BY
}

\section{THREE-DIMENSIONAL, PERFECTLY PLASTIC ICE-SHEET}

\author{
MODELLING
}

\author{
by \\ N. Reeh \\ (Geophysical Isotope Laboratory, University of Copenhagen, Haraldsgade 6, \\ DK-2200 Copenhagen N, Denmark)
}

\section{ABST RACT}

A three-dimensional perfectly plastic ice-sheet model, developed for determining the surface elevations and the flow pattern of an ice sheet with given bottom topography and ice-margin positions, is applied to the reconstruction of the glacial ice covers of Greenland and the Canadian Arctic islands. In the northern regions, two different reconstructions have been performed with ice margins along the present 600 and $200 \mathrm{~m}$ sea-depth contours, respectively. In central Greenland, the ice margin is considered to be at the outermost ice-margin deposits on the coastal shelf to the west, and at the present $200 \mathrm{~m}$ sea-depth contour to the east.

The main conclusions to be drawn from the reconstructions are: (1). The flow pattern of the glacial ice cover of Greenland shows a great resemblance to the present one, the central ice divide being displaced less than $50 \mathrm{~km}$ from its present position and being no more than $200 \mathrm{~m}$ higher than today. (2). The main ice divide of the ice sheet covering the Canadian Arctic islands (the Innuitian ice sheet) was located over the highlands of eastern Ellesmere Island with local domes positioned over the present ice caps, indicating that even the deep ice of Wisconsin age in these ice caps is of local origin. This is also the case for the Devon Island ice cap. (3). Even in the not very likely case of a rather extensive glacial ice cover in north-west Greenland, the iceflow pattern upstream of the Camp Century deep drill site would not have changed radically compared to the present flow pattern. Thus it is concluded that even advanced ice margins in late-Wiscons in time could at most have resulted in an elevation of the deposition site of the late-Wiscons in ice at Camp Century $600 \mathrm{~m}$ higher than at present. The consequences of this conclusion are discussed.

\section{INT RODUCTION}

The extent of the late-Wiscons in ice cover in north-west Greenland has been discussed in several papers published with in the last decade, for example, Dansgaard and others (1973), Paterson (1977), Fisher (1979), and Budd and Young (1983).

One reason why this subject has attracted so much attention is the large shift in $\delta^{180}$ from lateWiscons in to Holocene times of $12 \%$ exhibited by the $\delta^{18} 0$ record from the deep ice core at Camp Century compared to significantly smaller $\delta$-shifts revealed by most of the other ice-core records (Dansgaard and others in press). The large $\delta$-shift has been ascribed to late-Wiscons in ice having been deposited at substantially higher elevations than present Camp Century elevations. Also, the total gas content of the late-Wiscons in Camp Century ice is lower than that of present-day ice and this has been interpreted similarly as an indication of deposition of ice at a higher elevation (Raynaud and Lorius 1977).

One possible way of producing the required higher elevations is by postulating more advanced margins of the north-west Greenland ice sheet in the lateWiscons in period, which could result in a substantial build-up of ice in the Camp Century area and/or a change of the flow pattern from the present highly divergent pattern with low flow velocities to a less divergent flow pattern, which would allow increased flow velocities, and hence permit ice from more distant regions of higher altitude to reach Camp Century in the 10 to $20 \mathrm{ka}$ that have elapsed since the time of deposition. In this context, it has been suggested (Dansgaard and others 1973) that the late-Wiscons in Camp Century ice might have originated from a high ice ridge across Nares Strait, connecting the northwest Greenland ice sheet to a former ice sheet covering the Canadian Arctic islands (the Innuitian ice sheet).

Paterson (1977) reviewed the geological and glaciological evidence for the existence of a lateWiscons in ice ridge in Nares Strait, of which the geological evidence, in particular, is ambiguous. on the bas is of mainly glaciological arguments, Paterson concluded that the deep Camp Century ice probably originates from central Greenland and later workers seem to accept this point of view.

The resolution of the problem concerning a lateWisconsin ice ridge across Nares Strait will probably have to await collection of further geomorphological data. However, one useful exercise can be carried out immediately, viz. improving the modelling of the ice flow in the Camp Century region, which so far has been based on very simple considerations, at least as far as the possible changes of the ice-fiow pattern 
are concerned. The model to be applied in order to establish the flow pattern more accurately is a threedimensional, perfectly plastic ice-sheet model, which determines the flow pattern and surface elevations of an ice sheet for given basal topography and icemargin positions (Reeh 1982).

The reconstructed flow pattern of the glacial ice cover of north-west Greenland confirms Paterson's (1977) conclusion in so far as the origin of the Camp Century flowline is concerned: even in the case of widely advanced ice margins and irrespective of the existence of an ice ridge in Nares Strait, the Camp Century flowline merges with the ice divide running from north-west Greenland southward towards central Greenland.

However, the reconstruction raises another question, viz. whether the change of elevation of the north-west Greenland ice sheet in the late-Wiscons in is sufficient to explain the large shift in $\delta^{180}$ in the Camp Century record from the late-Wiscons in to the Holocene.

\section{THE ICE-SHEET MODEL}

The ice-sheet model to be applied has been described in detail by Reeh (1982). Characteristics of the model, which are essential for discussion in the present paper, will be briefly summarized.

The model is a steady-state, three-dimensional model based on the assumption that the ice sheet behaves as a perfectly plastic continuum. This means that the basal shear stress is assumed not to vary along the flowlines (Orowan 1949), which are defined as trajectories orthogonal to the elevation contours of the surface.

As input, the model uses the topography of the landscape covered by the ice sheet and the position of the edge of the ice sheet. Furthermore, a value of the basal shear stress must be specified.

The output of the model calculations are flowline directions and profiles of surface elevation along the calculated flowline courses. So, contrary to many of the other steady-state models used to reconstruct iceage ice covers (e.g. Sugden 1977, Denton and Hughes 1981) which apply ice-sheet profiles based on empiricism or rather sophisticated ice-flow theory along more or less subjectively defined flowlines, this model applies the simplest possible ice-sheet profiles, viz. profiles based on perfect plasticity theory. These profiles, however, are applied along flowlines, the courses of which are calculated by means of the model. The flow pattern and the topography of the ice-sheet surface are then constructed as a synthes is of calculated variations along individual flowlines.

\subsection{Basal shear stress}

The question of how to specify the basal shear stress deserves some attention. Generally the basal shear stresses in the flow regions of the present large ice sheets in Antarctica and Greenland range between 0.5 to 1.5 bar, depending on accumulation rate, basal ice temperature, etc.

The choice of the magnitude of the shear stress has a substantial influence on the surface elevation calculated by means of the model. The maximum ice thickness $\mathrm{H}_{0}$ of a two-dimensional, perfectly plastic ice sheet on a horizontal base is determined by the equation

$$
H_{O}=\left(2 \tau_{0} /(\rho g)\right)^{1 / 2} L^{1 / 2},
$$

where $\tau_{0}$ is basal shear stress, $\rho$ the density of ice, $g$ the gravitational acceleration, and $\mathrm{L}$ the distance between the ice divide and the ice margin.

If, more realistically, the ice is assumed to obey a Glen-type flow law (see, for example, Paterson 1981:
26 ) the following expression is obtained for the maximum ice-sheet thickness:

$$
H_{0}=(K a / A(T))^{1 /(2 n+2)} L^{1 / 2} \text {, }
$$

where $K$ is a constant, a the accumutation rate, $A(T)$ the temperature-dependent parameter of the flow law (Paterson 1981: 26), T the temperature of the basal ice, and $n \sim 3$ a flow-1 aw constant.

Comparing Equation (2) with Equation (1) shows that the same value of $\mathrm{H}_{0}$ for fixed $\mathrm{L}$ will be obtained by the two formulae if we put

$$
\tau_{0}=1 / 2 \rho g(K a / A(T))^{1 /(n+1)} .
$$

This equation is a guide to changing the shear stress from one region of the ice sheet to another if the distributions of the accumulation rate and the basal temperature are known.

\subsection{Depression of the base of the ice sheet}

In the model, if local isostatic equilibrium is assumed, it is straightforward to calculate the isostatic depression of the ice-sheet base due to loading by the ice cover (Reeh 1982).

With regard to areas which are now covered by sea and over which glacial ice covers are to be modelled, the sea-bed depths have been reduced in order to allow for the rebound due to removal of the sea-water load, before the bed is re-depressed by the load of the ice cover.

\section{RECONSTRUCTIONS OF GLACIAL ICE COVERS}

\subsection{Test of the model}

The model has been tested by constructing the flow pattern and the surface topography of the present ice sheet covering central Greenland, and comparing this with the pattern deduced from ice-sheet elevations obtained during radio echo-sounding flights (Gudmandsen 1978).

As shown in Figure 1 , there is a general agreement between the constructed and the observed flow patterns of the ice sheet. Also, elevations along the central ice divide show a good match, whereas the model underestimates the elevations on the slopes of the ice sheet by up to $200 \mathrm{~m}$, as is to be expected when applying a perfect plasticity model (Reeh 1982: 434).

3.2. Glacial ice cover of central Greenland

The reconstruction of the glacial ice cover of central Greenland is shown in Figure 2. To the west the ice margin is located by the outermost deposits on the coastal shelf (Weidick undated). To the east a position is chosen, coincident with the present $200 \mathrm{~m}$ sea-depth contour, except at the outermost coast of the Scoresbysund region where there is evidence of ice-free areas during Wisconsin time (Funder and Hjort 1973). The value of the basal shear stress used in the reconstruction is equal to 0.9 bar $(90 \mathrm{kPa})$, which value was also applied for constructing the present ice cover shown in Figure 1. One might speculate in which direction the basal shear stress should be changed in order to account for the different regimes of temperature and accumulation rate prevailing over the surface of the ice sheet in glacial times, i.e. lower surface temperatures and, probably, lower accumulation rates.

After several thousand years of decreased surface temperatures, a cold wave will reach the basal layers of the ice sheet, making the ice more rigid. Consequently an increase of the basal shear stress is required in order to maintain the ice flux at an unchanged level. However, at the same time the ice flux is probably decreased because of a low (i.e. lower than present) accumulation rate. Furthermore, a low accumulation rate will, after some thousands of years, tend to increase basal ice temperatures, thus counteracting the trend induced by the decreased sur- 


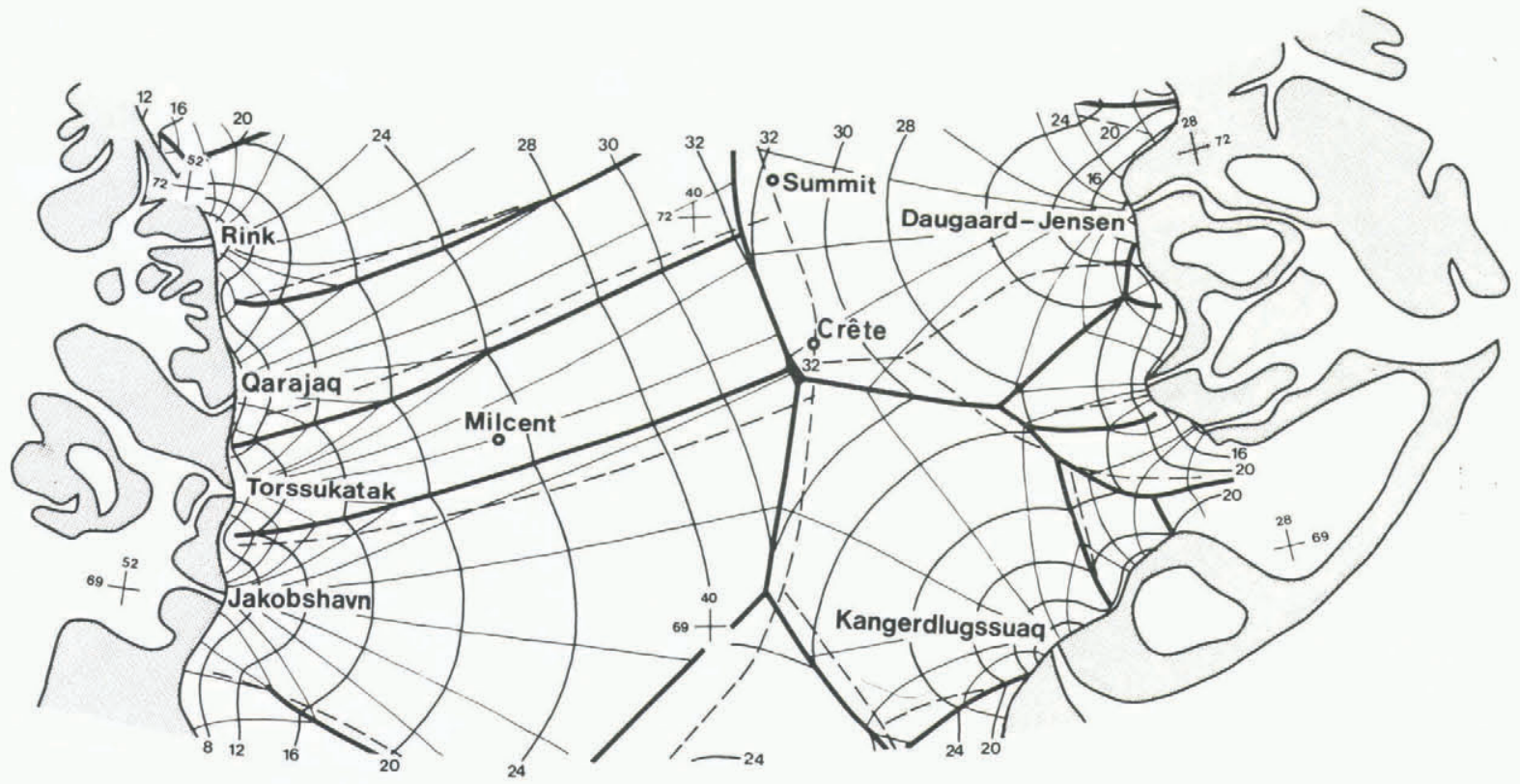

Fig.1. Reconstruction of the present ice sheet of central Greenland (from Reeh 1982). Heavy full lines are ice divides deduced from lices are $100 \mathrm{~m}$ contours, thin full lines are flowlines. Dashed lines (Gudmandsen 1978 ).

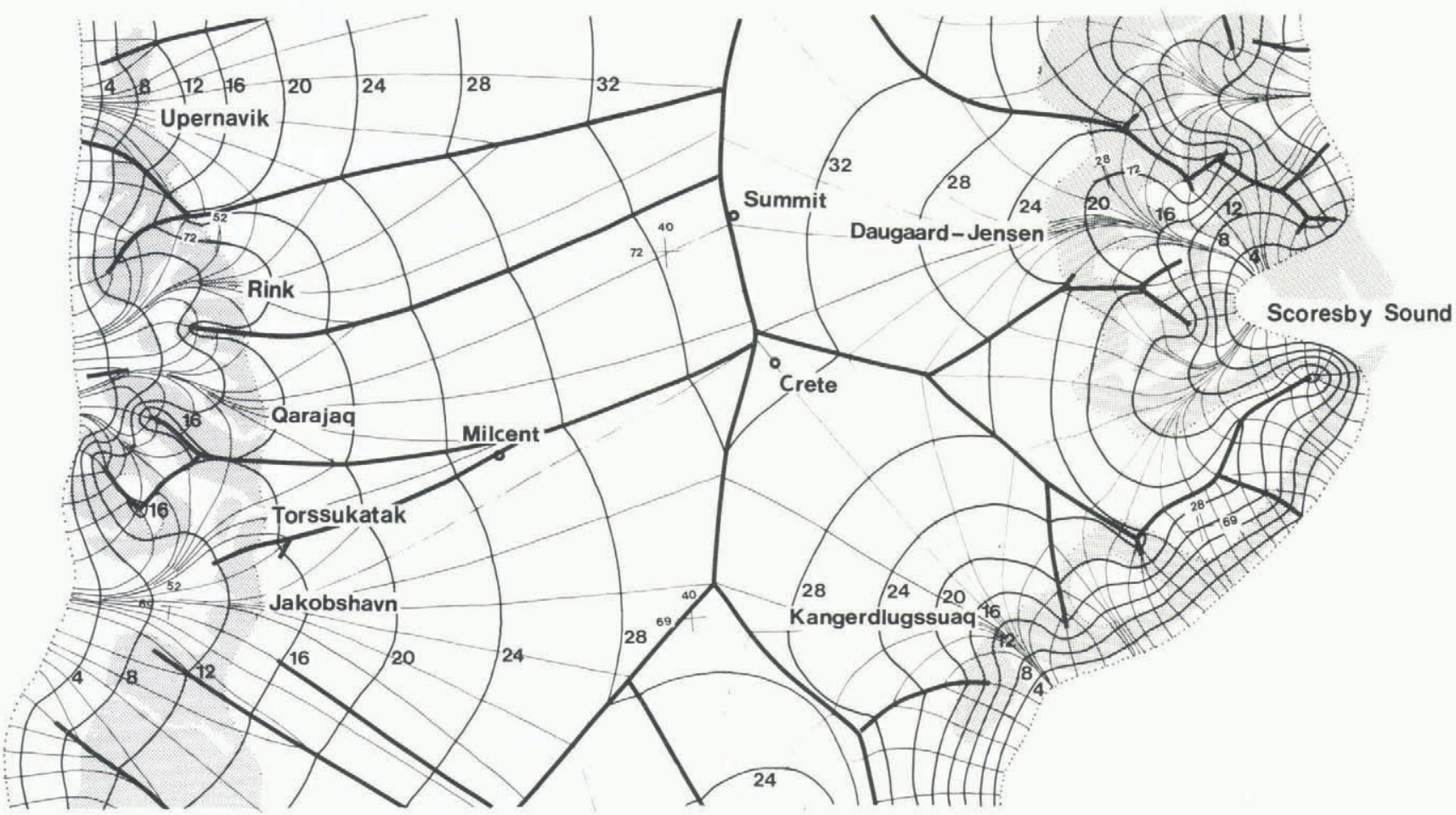

Fig.2. Reconstruction of glacial ice cover of central Greenland. Heavy full 1 ines are ice divides, medium full lines are $100 \mathrm{~m}$ contours, thin full lines are flowlines.

face temperatures. A reliable estimate of the probable trend of the basal shear stress, when changing to a glacial climate, involves elaborate non-

stationary ice-sheet modelling (see discussion in Budd and Young 1983). Since such modelling is beyond the scope of this paper, the basal shear stresses applied to reconstruct the glacial ice covers have been maintained at their present values.

It appears from Figures 1 and 2 that the reconstructed pattern of glacial flow shows a marked resemblance to present conditions: (i) a south-north main ice divide, displaced less than $50 \mathrm{~km}$ from its present position, (ii) maximum elevations along this divide no more than $200 \mathrm{~m}$ higher than present elevations, and (iii) major ice streams positioned at nearly the same locations as today.

The modest change of surface elevation in the central part of the ice sheet, obtained for even a rather large advance of the ice margin, seems to be inconsistent with Equation (1), which predicts ice thickness to change as the square root of the lateral extent of the ice sheet. There are two reasons for 
Reeh: Reconstructing continental Arctic ice cover

a.

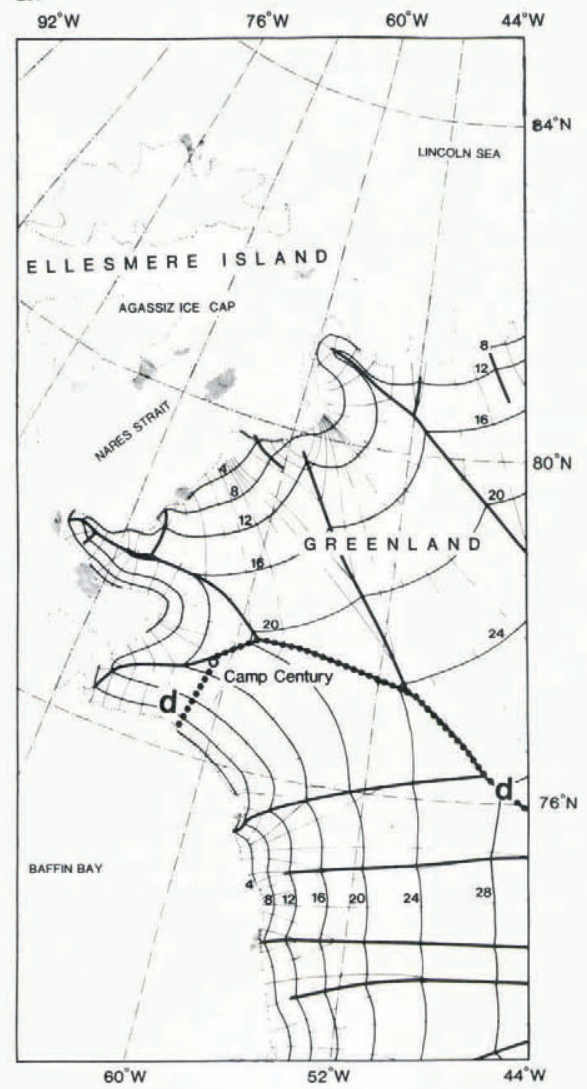

b.

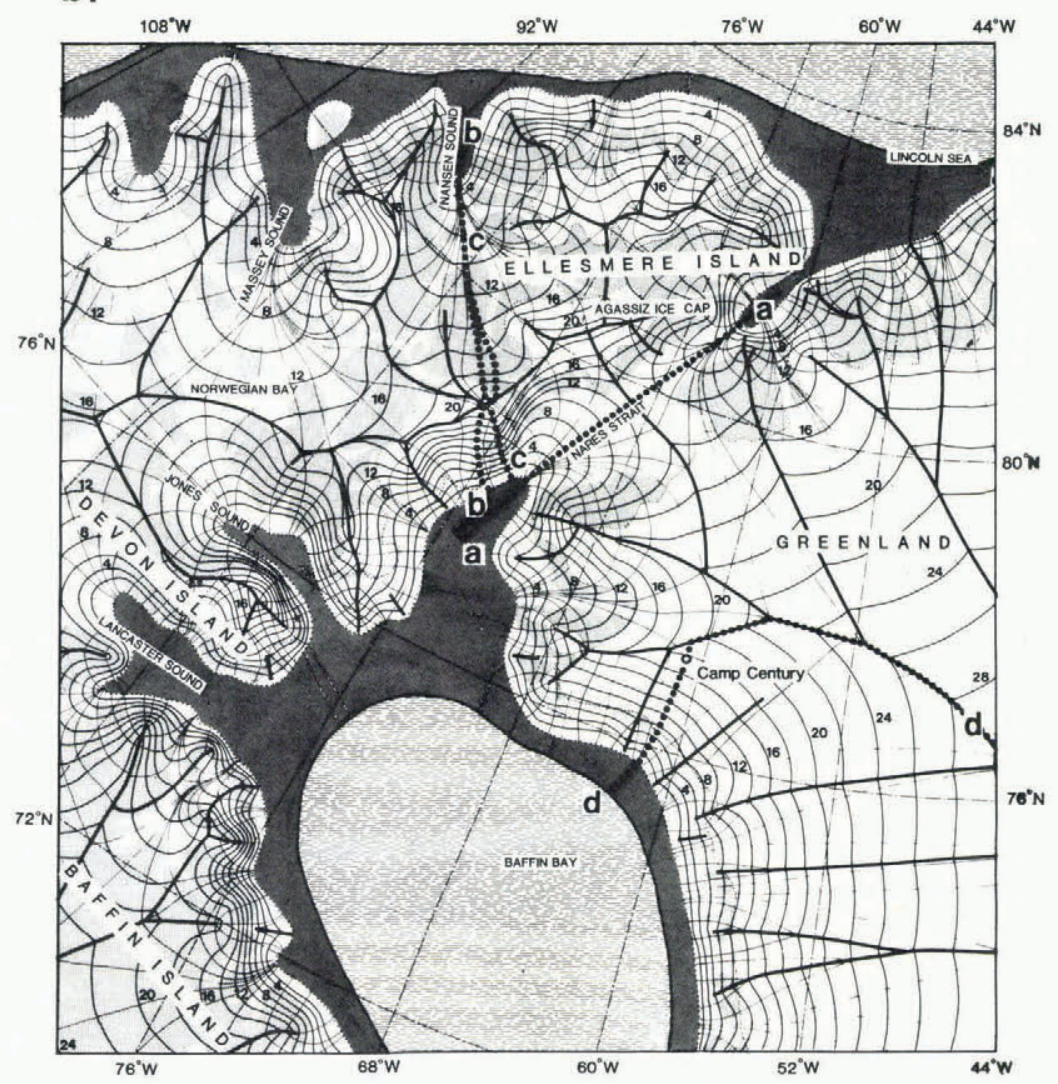

c.

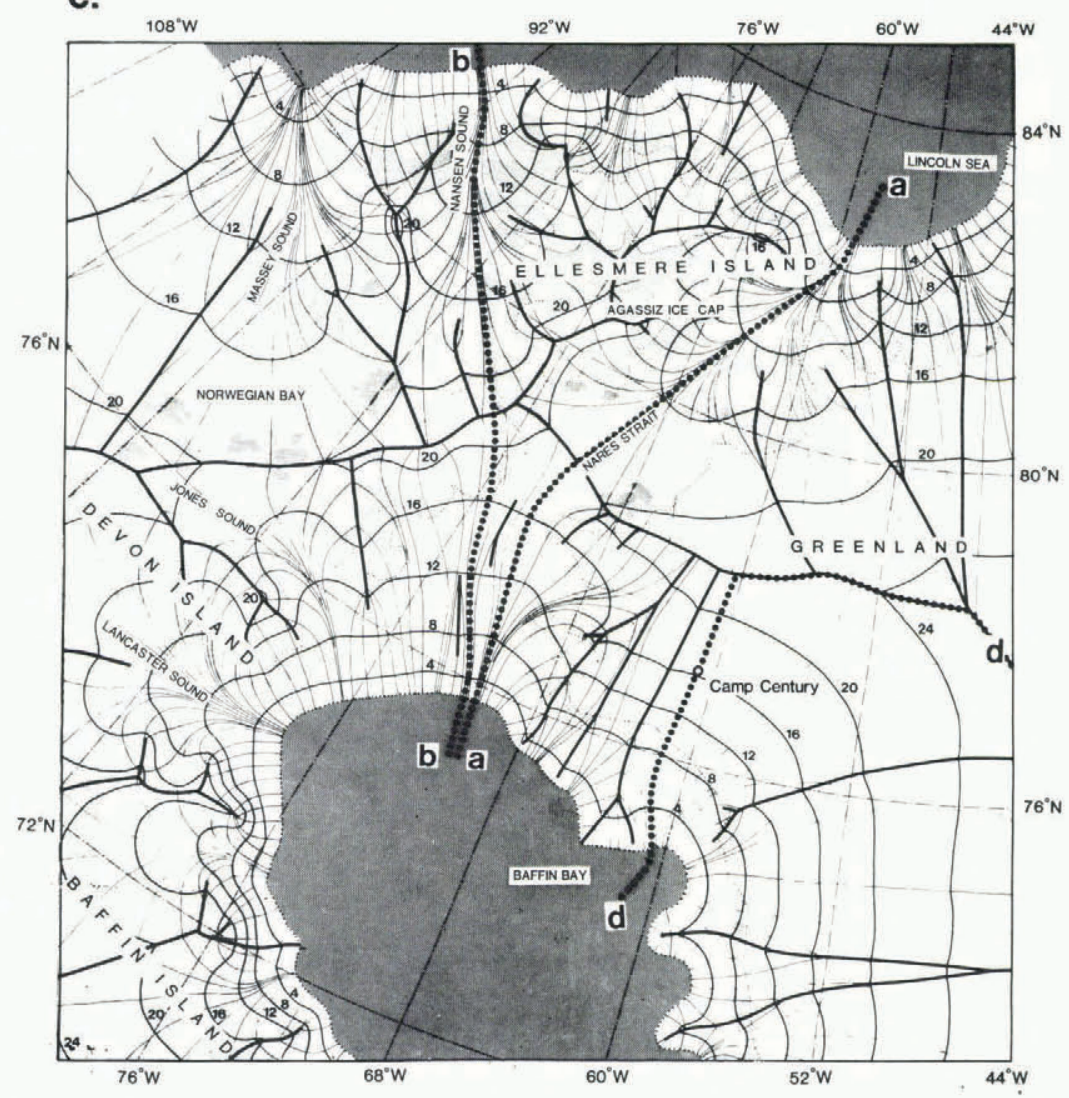

Fig.3. Reconstruction of (a) the present ice cover of north-west Greenland, and (b) and (c) glacial ice covers of north-west Greenland and the Canadian Arctic islands with ice margins (ice-shelf/ice-sheet transition lines) along the present 200 and $600 \mathrm{~m}$ sea-depth contours, respectively. Heavy full 1 ines are ice divides, medium full 1 ines are $100 \mathrm{~m}$ contours, thin full lines are flow 1 ines. Dotted lines indicate positions of the profiles shown in Figure $4(a-a, b-b-$ and $c-c)$ and Figure $6(d-d)$. Present ice-free land is indicated by light shading, whereas dark shaded areas indicate assumed extent of ice shelves. 
this modest change: (i) the isostatic depression of the base of the ice sheet, resulting in a lowering of the surface elevation by about $15 \%$ (and a thickening of the ice sheet by a similar amount), compared to the value calculated by Equations (1) or (2), and (ii) a topographical effect due to the fact that the ice sheet expands over a terrain of decreasing elevation.

3.3. Glacial ice cover of north-west Greenland and the Canadian Arctic islands

Figure 3 shows two reconstructions of the glacial ice covers of north-west Greenland, and the Canadian Arctic islands (the Innuitian ice sheet), with icemargin positions corresponding to ice-sheet grounding lines (ice-sheet/ice-shelf transition 1 ines) along the 200 and $600 \mathrm{~m}$ sea-depth contours, respectively. Also shown in the figure is the modeling of the present ice cover of north-west Greenland. In all reconstructions, two different values of the basal shear stress have been applied: for ice-sheet slopes facing Baffin Bay a value of $\tau_{0}=0.9$ bar $(90 \mathrm{kPa})$ has been applied, whereas a value of $\tau_{0}=0.65 \mathrm{bar}$ $(65 \mathrm{kPa})$ is used for the slopes facing the Arctic ocean. These values were found appropriate for a good match between the constructed and observed flow patterns of the present north-west Greenland ice cover. The need for applying a lower shear-stress value for the slopes facing the Arctic Ocean reflects a difference by a factor of 2 between the accumulation rates on the north-west and south-west-facing slopes of the present north-west Greenland ice sheet (Radok and others 1982: fig.2.3). A difference of the same magnitude probably also existed in glacial times, justifying the application of two values of the basal shear stress also for the reconstructions of the glacial ice covers.

Both reconstructions imply an ice ridge across Nares Strait connecting the north-west Greenland and the Innuitian ice sheets, with saddle point elevations of 1300 and $1900 \mathrm{~m}$ respectively (see profiles in Figure $4(a))$. A reconstruction based on a minimum extent with separated Greenland and Innuitian ice sheets (a situation which was not at all unlikely during the last glacial maximum, see discussion in Paterson (1977).) has not been performed, since an important purpose of the reconstructions is to assess "worst case" situations concerning changes of icesheet elevations and ice-flow patterns.

As for the Innuitian ice sheet, both reconstructions imply a south-west to north-east main ice divide exhibiting several domes with elevations up to 2100 and $2300 \mathrm{~m}$, respectively, and ice thicknesses around $500 \mathrm{~m}$, positioned above the present local ice caps of Ellesmere and Devon islands. This indicates that these locations were never overridden by ice deposited at high elevations on some distant ice dome. Hence, even the deep Wisconsin ice contained in these ice caps is of local origin. The position of the ice divide above the highlands of eastern Ellesmere Island is in agreement with the direction of inferred former ice flows (Blake 1970).

The maximum ice thickness of the Innuitian ice sheet as deduced from the two reconstructions was of the order of magnitude of 1500 and $2000 \mathrm{~m}$ respectively (see profiles in Fig.4(b)). These occurred west of the crest of the ice sheet in the Nansen Sound and

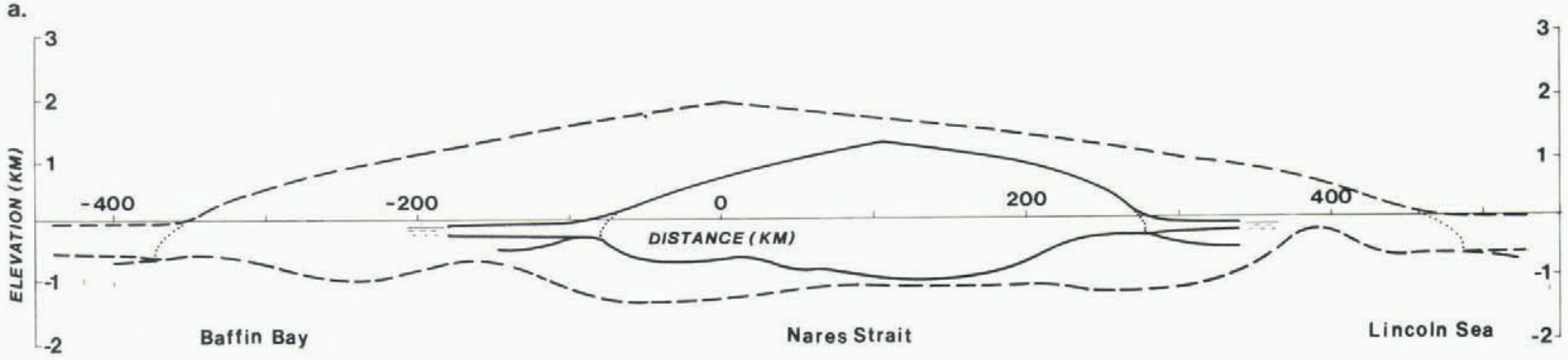

b.
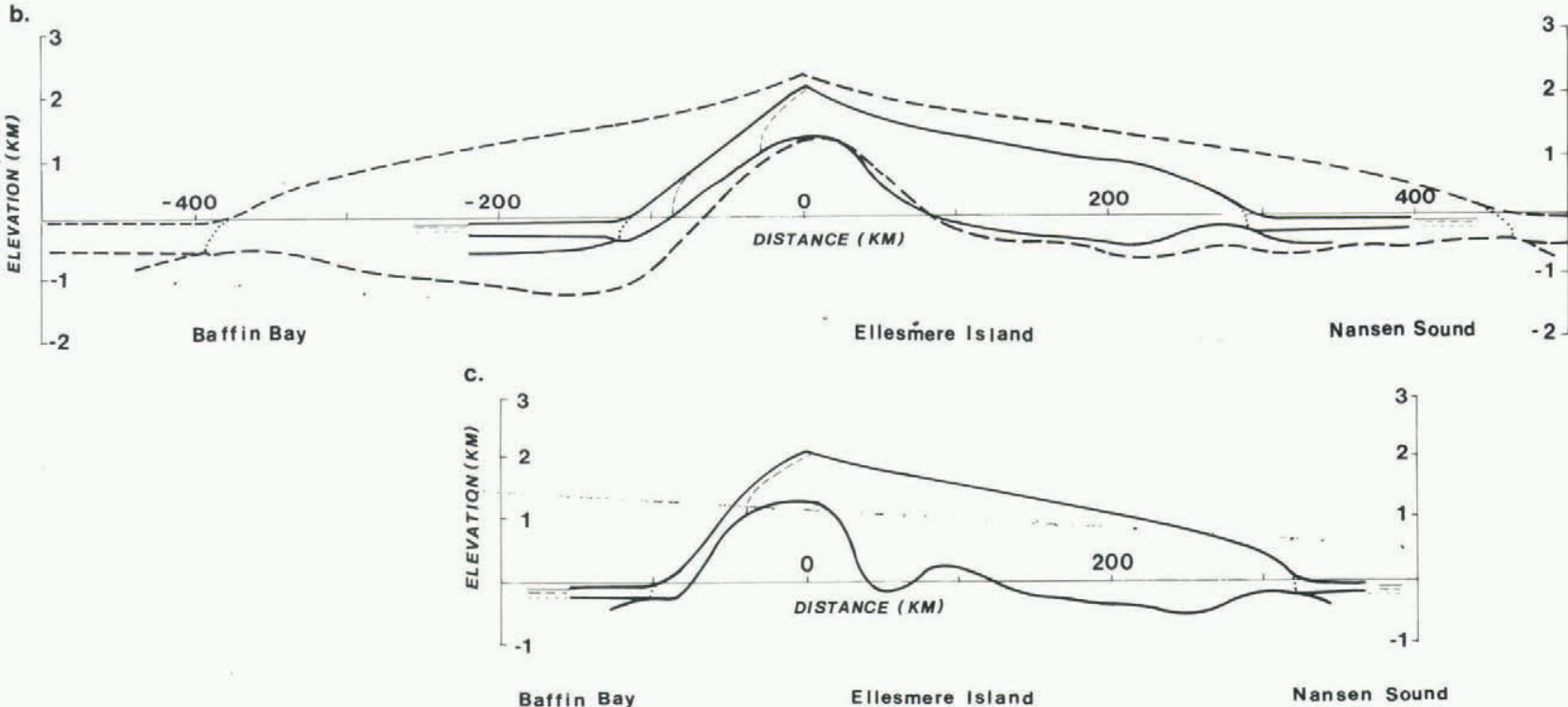

Fig.4. Surface- and base-elevation profiles along selected cross-sections of the reconstructed Innuitian ice sheet. Profiles drawn by heavy full lines, and heavy dashed lines correspond to the ice-sheet reconstructions shown in Figure $3(\mathrm{~b})$ and (c) respectively. (a), (b) and (c) show profiles along the dotted lines shown in Figure 3 marked with $a-a, b-b$, and $c-c$, respectively. 
Norwegian Bay regions, in accordance with the observed post-glacial rebound pattern (Walcott 1972).

Also, both reconstructions imply major ice streams in Nansen and Massey sounds, discharging into the Arctic 0cean, and, similarly, large ice streams in Jones and Lancaster sounds, discharging into Baff in Bay. The calculated ice thickness on the steep eastfacing slopes of Ellesmere Island is no more than $200 \mathrm{~m}$ (see cross-section in Fig.4(c)). Most probably, the ice flow down such steep slopes was concentrated in valleys with ice-free areas (nunataks) in between them.

Figure $4(\mathrm{~b})$ and (c) also demonstrates that a separation of the Innuitian ice sheet from the northwest Greenland ice sheet need not seriously affect the patterns of flow and surface elevations, except locally in the Nares Strait region. This is due to the topographical effect discussed above, which is further illustrated in Figure 5 . This shows twodimensional, perfectly plastic ice-sheet profiles on a plane-sloping base of slope angle $B$. Contrary to the case with a horizontal base, for which there is only one solution for the surface profile (the second-order parabola, given by Equation (1)), there are three possible solutions when the base is sloping (Nye 1951). One solution is flow with a uniform ice

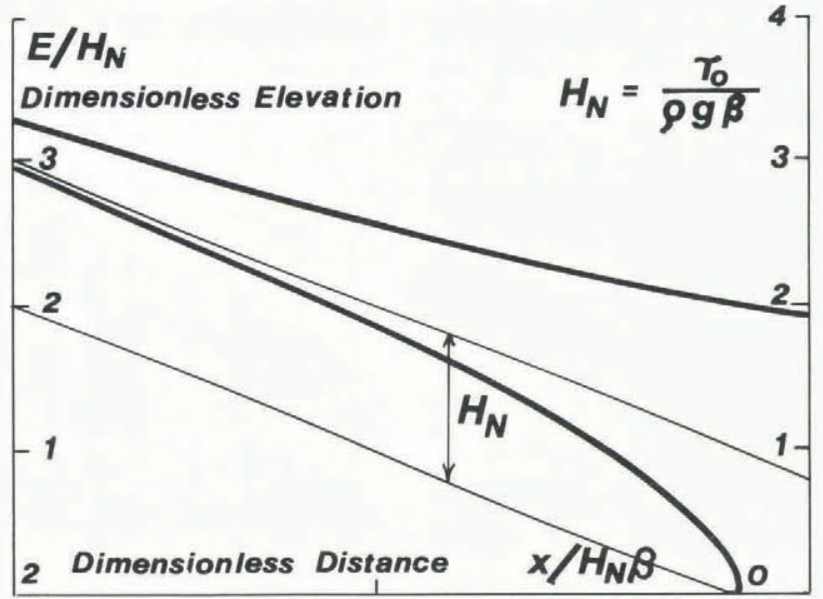

Fig.5. Two-dimensional, perfectly plastic ice-sheet profiles on a plane-sloping base.

thickness equal to $H_{N}=\tau_{0} / \rho g \beta$; the others are flows with decreasing $H\left(<\mathrm{H}_{N}\right)$ and increasing $H\left(>H_{N}\right)$ ice thicknesses, respectively. Both non-uniform profiles approach asymptotically the profile with uniform ice thickness, when going in the upslope direction.

Therefore, if the slope is long enough, the ice thickness at the upslope end will have a value close to $H_{N}$ independent of the downslope extent of the ice sheet. This means that a retreat of the margin of the Innuitian ice sheet up the steep slopes of Ellesmere Island will not change the ice thickness at the crest significantly, and therefore will have only a minor influence on the topography and the flow pattern of the north-west-facing slopes.

\section{THE CAMP CENTURY FLOWLINE}

Figure 6 shows various profiles along the Camp Century flowline. In Figure $6(a)$ the modelled profile of the present situation is compared with the corresponding profile as obtained from Weidick (undated). With the exception of the outermost steep parts, where the model underestimates the surface elevations, the profiles agree fairly well. Figure 6 (b) compares the profiles along the Camp Century flowlines of the two different reconstructed glacial ice covers with the modelling of the actual profile. It appears from this figure that neither the surface slopes nor the ice thicknesses upstream from Camp Century were radically changed, not even in the case

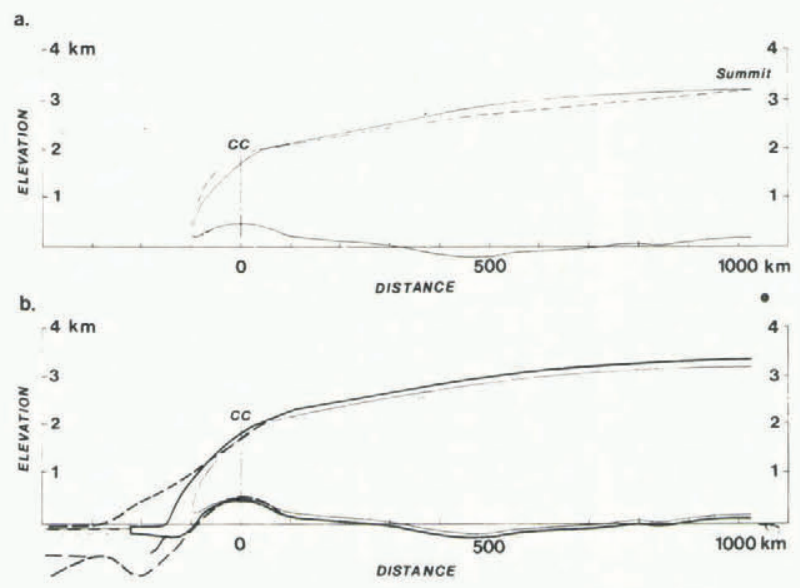

Fig.6. Surface- and base-elevation profiles along the Camp Century flowline extending from the margin of the ice sheet to central Greenland (sections d-d in Figure 3 ). The full thin line shows the reconstructed present profile, the dashed thin line shows the profile obtained from Weidick (undated). Profiles drawn by heavy full lines and heavy dashed lines correspond to the ice-sheet reconstructions shown in Figure $3(b)$ and (c) respectively.

of the most advanced positions of the ice margin. Along the nearest $100 \mathrm{~km}$ upslope of Camp Century, though, surface slopes were increased to values that are of the same order of magnitude as the present surface slope at Camp Century. Assuming the flow velocity along this section of the flowline to be equal to the present surface velocity at Camp Century, which is of the order of magnitude of $5 \mathrm{~m} \mathrm{a}^{-1}$, this will place an upper limit of $100 \mathrm{~km}$ to the distance which the ice could have moved during the 15 to $20 \mathrm{ka}$ that have elapsed since the late-Wiscons in period. This means that ice of this age cannot have been deposited at a surface elevation greater than $600 \mathrm{~m}$ above the present height of Camp Century, and that it was most probably at a considerably lower site (see profiles in Fig.6(b)).

In other words, advanced ice-margin positions in north-west Greenland during the late-Wiscons in period cannot account for a change in the elevation of the snow-deposition site of Camp Century ice of 1200 to $1500 \mathrm{~m}$, as suggested by, for example, Fisher (1979) and Budd and Young (1983). To produce such a large change, the advance of the ice margin must be combined with an increase of the basal shear stress of $60 \% \mathrm{com}-$ pared to its present value (see Equation (1)). This change could have been produced by an increase of the accumulation rate by a factor of 6 or 7 or by a lowering of the basal ice temperature by $15^{\circ} \mathrm{C}$. Neither of these possibilities seems to be very likely.

Therefore, other explanations of the large $\delta$ shift at Camp Century should be considered, for example, an anomalously high climatic temperature shift or an anomalously high $\delta$-change per degree of warming in the area, as suggested by Dansgaard and others (in press).

REFERENCES

Blake W Jr 1970 Studies of glacial history in Arctic Canada. 1. Pumice, radiocarbon dates, and differential postglacial upl ift in the eastern Queen Elizabeth Islands. Canadian Joumal of Earth Sciences 7(2): 634-664

Budd W F, Young N W 1983 Techniques for the analys is of temperature-depth profiles in ice sheets. In Robin $G$ de $Q(e d)$ The climatic record in polar ice sheets. Cambridge etc, Cambridge University Press: $145-150$ 
Dansgaard W, Johnsen S J, Clausen H B, Gundestrup N 1973 Stable isotope glaciology. Meddelelser om Grbnland 197(2)

Dansgaard W, Clausen H B, Gundestrup N, Johnsen S J, Rygner $C$ In press Dating and climatic interpretation of two deep Greenland ice cores. American Geophysical Union, GISP Monograph

Denton G H, Hughes T J 1981 The last great ice sheets. New York etc, John Wiley and Sons

Fisher D A 1979 Comparison of $10^{5}$ years of oxygen isotope and insoluble impurity profiles from the Devon Island and Camp Century ice cores. Quatemary Research 11(3): 299-305

Funder S, Hjort C 1973 Aspects of the Weichselian chronology in central East Greenland. Boreas 2(2): 69-84

Gudmandsen P E 1978 Application of space techniques in solid earth physics. In Gudmandsen P $E$, Kejlsø $E$, Tscherning C C (eds) The conference on application of space techniques in navigation, geodesy, oceanography and solid earth physics, Kbbenhavn, 27. September 1978. Charlottenlund, Dansk Nationalkomité for den Internationale Union for Geodæsi og Geofysik: $84-94$

Nye J F 1951 The flow of glaciers and ice-sheets as a problem in plasticity. Proceedings of the Royal Society of London Ser A 207: 554-572

Orowan E 1949 Joint meeting of the British Glaciological Society, the British Rheologists' Club and the Institute of Metals. Joumal of Glaciology $1(5): 231-240$

Paterson W S B. 1977 Extent of the late-Wiscons in glaciation in northwest Greenland and northern Ellesmere Island: a review of the glaciological and geological evidence. Quatemary Research 8(2): $180-190$

Paterson W S B 1981 The physics of glaciers. Second edition. 0xford etc, Pergamon Press

Radok U, Barry R G, Jenssen D, Keen R A, Kiladis G N, McInnes B 1982 Climatic and physical characteristics of the Greenland ice sheet. Boulder, CO, University of Colorado. Cooperative Institute for Research in Environmental Sciences

Raynaud D, Lorius C 1977 Total gas content in polar ice: rheological and climatic implications. Inter national Association of Hydrological Sciences Publication 118 (General Assembly of Grenoble 1975 Isotopes and Impurities in Snow and Ice): 326-335

Reeh N 1982 A plasticity theory approach to the steady-state shape of a three-dimensional ice sheet. Joumal of Glaciology 28(100): 431-455

Sugden DE 1977 Reconstruction of the morphology, dynamics, and thermal characteristics of the Laurentide ice sheet at its maximum. Arctic and Alpine Research 9(1): 21-47

Walcott R I 1972 Late Quaternary vertical movements in eastern North America: quantitative evidence of glacio-isostatic rebound. Reviews of Geophysics and Space Physics 10(4): 849-884

Weidick A Undated Quatermary map of Greenland. Copenhagen, Geological Survey of Greenland 